\title{
The GABA Receptor Agonist THIP Ameliorates Specific Behavioral Deficits in the Mouse Model of Fragile X Syndrome
}

\author{
Jose Luis Olmos-Serrano ${ }^{a}{ }^{1}$ Joshua G. Corbin ${ }^{a}$ Mark P. Burns ${ }^{b}$ \\ ${ }^{a}$ Center for Neuroscience Research, Children's National Medical Center, and b Department of Neuroscience, \\ Georgetown University Medical Center, Washington, D.C., USA
}

\section{Key Words}

Fragile $\mathrm{X}$ syndrome $\cdot \mathrm{GABA}_{\mathrm{A}}$ receptor agonist - Behavior

Developmental disabilities • Mouse model

\begin{abstract}
Hyperactivity, hypersensitivity to auditory stimuli, and exaggerated fear are common behavioral abnormalities observed in individuals with fragile $X$ syndrome (FXS), a neurodevelopmental disorder that is the most common genetic cause of autism. Evidence from studies of the Fmr1 knockout (KO) mouse model of FXS supports the notion that impaired GABAergic transmission in different brain regions such as the amygdala, striatum or cerebral cortex is central to FXS behavioral abnormalities. This suggests that the GABAergic system might be an intriguing target to ameliorate some of the phenotypes in FXS. Our recent work revealed that THIP (gaboxadol), a $\mathrm{GABA}_{\mathrm{A}}$ receptor agonist, can restore principal neuron excitability deficits in the Fmr1 KO amygdala, suggesting that THIP may also restore some of the key behavioral abnormalities in Fmr1 KO mice. Here, we reveal that THIP significantly attenuated hyperactivity in Fmr1 KO mice, and reduced prepulse inhibition in a volume-dependent manner. In contrast, THIP did not reverse the deficits in cued fear or startle response. Thus, this study shows that enhancing GABAergic transmission can correct specific behavioral phenotypes of the Fmr1 KO mouse further supporting that tar-
\end{abstract}

geting the GABAergic system, and specifically tonic inhibition, might be important for correcting or ameliorating some key behaviors in FXS.

Copyright $\odot 2011$ S. Karger AG, Basel

\section{Introduction}

Fragile $\mathrm{X}$ syndrome (FXS) is a rare genetic disorder that affects 1:4,000 males and 1:8,000 females [1]. Those with FXS display intellectual disabilities and exhibit a wide repertoire of behavioral abnormalities such as hyperactivity, abnormal social interactions, exaggerated fear, anxiety, and hypersensitivity to auditory stimuli. Collectively, this makes the fragile $\mathrm{X}$ mental retardation 1 (FMR1) the most prominent single gene associated with autism [2]. FXS is caused by the transcriptional inactivation of FMR1, leading to a decrease or absence of FMRP, the protein product of FMR1. FMRP is an mRNA-binding protein that is expressed ubiquitously and abundantly in neurons and glia during development, postnatally and in adult brain. FMRP is widely believed to participate in neurite morphogenesis, dendritic spine density forma-

Current address: Department of Anatomy and Neurobiology, Boston University School of Medicine, Boston, Mass., USA

\section{KARGER}

(๑) 2011 S. Karger AG, Basel

Fax +4161306 1234

E-Mail karger@karger.ch

www.karger.com
Accessible online at: www.karger.com/dne
Mark P. Burns

Department of Neuroscience

Georgetown University Medical Center, Research Building WP22a

3970 Reservoir Rd. NW, Washington, DC 20007 (USA)

Tel. +1 202687 4735, E-Mail mpb37@georgetown.edu 
tion, and synaptic plasticity [3-7]. Our understanding of the pathogenesis of this disorder has increased significantly since the generation of the mouse model, the Fmr1 knockout (KO) mouse, which exhibits many characteristics that resemble abnormal behaviors in humans with FXS such as hyperactivity, anxiety, and increased sensitivity to auditory stimuli [8-10]. Recently, novel targets for treatment of FXS have been developed, many of which are based on the 'mGluR theory' which posits that disrupted metabotropic glutamate receptor 5 synaptic plasticity underlies many of the FXS phenotypes. This theory, in large part, has been validated by pharmacological and genetic approaches in Fmrl KO mice, which have led to novel therapeutic approaches for fragile $\mathrm{X}$, which pharmacologically target mGluR signaling $[11,12]$.

In addition to alterations in glutamatergic transmission, mounting evidence from studies of Fmrl KO mice indicate alterations in the expression of several important presynaptic and postsynaptic components of the inhibitory transmission machinery, including $\mathrm{GABA}_{\mathrm{A}}$ receptor subunits, GABA transporters, glutamic acid decarboxylase, and gephyrin in different brain regions [13-18]. This evidence has led to a complementary 'GABA theory' [19], which argues that targeting the GABAergic system may also be an important approach for treatment in FXS. This approach is supported by studies in the Drosophila model of FXS, which have identified three molecules implicated in the GABAergic inhibitory pathway that were able to rescue several known fmrl mutant phenotypes, including mushroom body defects, excess Futsch translation and abnormal male courtship behavior [20]. In addition, it has been reported that taurine, a $\mathrm{GABA}_{\mathrm{A}}$ receptor agonist, has been shown to improve cognitive functions in a mouse model of FXS [21]. We have recently reported that THIP, a superagonist at $\delta$-subunit-containing presynaptic and extrasynaptic $\mathrm{GABA}_{\mathrm{A}}$ receptors that mediates strong tonic inhibitory conductance in the CNS $[13,22]$, restored principal neuron excitability in amygdala slices from Fmrl KO mice to wild-type (WT) levels [18]. This suggested that acute treatment of THIP might also restore specific behavioral abnormalities in Fmrl KO mice. Previous studies have consistently shown pronounced hyperactivity, reduced retention of cued and spatial fear, and increased prepulse inhibition (PPI) in Fmrl KO mice [9, 23-25]. Consistent with previous studies, we reveal that these behavioral paradigms are similarly altered in Fmrl KO mice. Importantly, extending this work, our study shows that acute THIP treatment in Fmrl KO mice reverses specific key behavioral abnormalities, and thus supports the view that enhancing GABAergic transmission via tonic inhibition might be a reliable way to ameliorate some core symptoms in FXS.

\section{Materials and Methods}

\section{Animal Usage and Housing}

Male Fmr1 WT (stock No. 4828) and Fmr1 KO (stock No. 4624) mice were on the congenic FVB mouse background and obtained from The Jackson Laboratory (Bar Harbor, Me., USA). For these studies, 3-month-old mice were used. Mice were maintained according to protocols approved by the Georgetown University Animal Care and Use Committee. Standard rodent chow and water were available ad libitum. The colony room was maintained on a 12-hour light/12-hour dark cycle at a temperature of $20^{\circ} \mathrm{C}$ and $55 \%$ humidity.

THIP was dissolved in sterile saline (0.89\%), and injected intraperitoneally $30 \mathrm{~min}$ prior to testing at a volume of $10 \mathrm{ml} / \mathrm{kg}$. The final dose was $3 \mathrm{mg} / \mathrm{kg}$.

\section{Open Field Test}

Locomotion was measured as the spontaneous activity of mice in a novel open square arena $(2 \times 2 \mathrm{ft})$ brightly lit with overhead lights. Mice were tracked using the Topscan tracking system (Clever Sys Inc., Va., USA), as previously described [26]. Mice were tracked for $30 \mathrm{~min}$, and the distance travelled and velocity were electronically recorded. We also analyzed the time spent in the center of the maze.

\section{Fear Conditioning}

Fear conditioning is a behavioral test in which mice learn to anticipate an adverse event. In our contextual fear conditioning paradigm, mice learn to associate a spatial environment (the apparatus) with the adverse event (footshock). For cued fear conditioning, mice were trained to associate an auditory cue with the adverse event. Cued fear conditioning is dependent on a functioning amygdala, but contextual fear conditioning also involves the hippocampus.

Acclimatization. On the day prior to training, the mice were acclimated to the test chamber for $8 \mathrm{~min}$. The chamber consists of a clear Plexiglass $10 \times 8$-inch rectangular cage with a grid floor (Clever Sys Inc.). This is housed in a slightly larger box containing a house light, speaker and compact digital camera. The chamber was cleaned between animals using 95\% ethanol.

Training. The training day involved returning the animals to the test chamber and exposing them to three consecutive training protocols consisting of a 2-min exploration followed by a 30 -second nonaversive tone (the conditioned stimulus), followed immediately by a continuous 0.40 - $\mathrm{mA}$ shock (the unconditioned stimulus) for $1 \mathrm{~s}$. There was an additional rest period after the final training session before the mice were returned to their home cage.

Contextual Test. Twenty-four hours after training, the animals were scored for contextual fear by returning them to the exact same training chamber and observing them for freezing over a 5 -min period. There was no conditioned stimulus or footshock.

Cued Test. Two hours after the contextual test, the mice were placed back in the chamber. To remove the contextual cues, the inside of the cage was altered. The grid floor was covered with a white plastic insert. The walls were covered with a nonporous, 

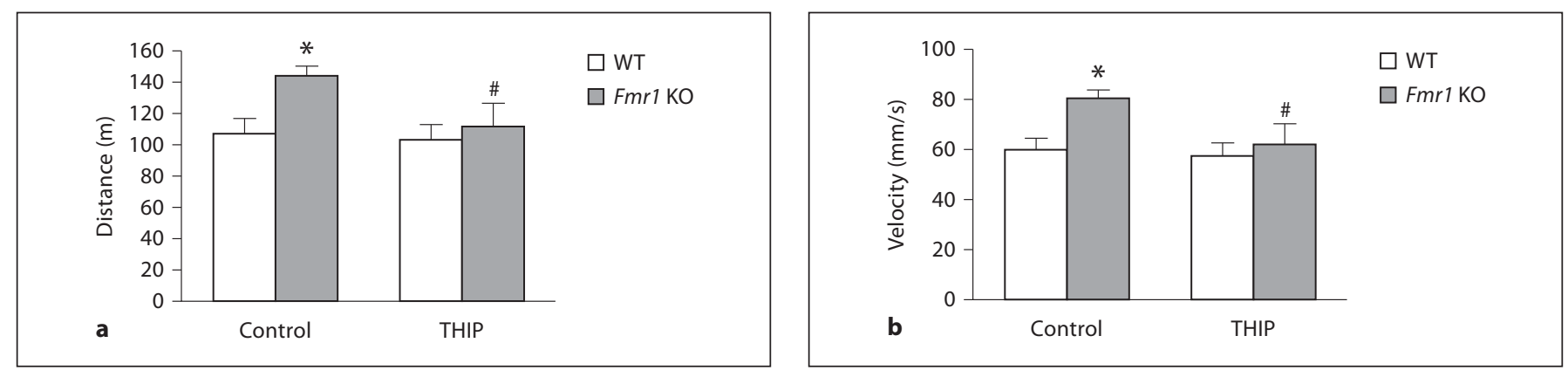

Fig. 1. THIP prevents hyperactivity in Fmr1 KO mice. Distance travelled (a) and average velocity (b) of WT and Fmr1 KO mice in an open field test. Mice were tracked using a video-monitoring system over a 30-min period. ${ }^{*} \mathrm{p}<0.05$ vs. WT control; ${ }^{\#} \mathrm{p}<0.05$ vs. Fmr1 KO control. ANOVA and Newman Keuls post hoc. $\mathrm{n}=8$ per group.

orange, foam/plastic insert with a curved roof. To remove olfactory cues, the cage was wiped with a disinfectant instead of alcohol, and further wiped with water to reduce the odor. The mice were given $2 \mathrm{~min}$ for free exploration before presentation of a 30 -second conditioned stimulus, as above. Freezing was measured from the start of the stimulus for a 2-min interval.

\section{Auditory Startle Testing and PPI}

The acoustic startle response (ASR) is typified by a flinching response to an auditory stimulus. The startle response can be reduced when the auditory stimulus is immediately preceded by a weaker stimulus, a process known as PPI. ASR and PPI were measured using the SR-LAB startle response system (San Diego Instruments, San Diego, Calif., USA), as previously reported [27]. The soundproof chamber $(16 \times 15 \times 23)$ houses a Plexiglass mouse chamber $(3.8 \mathrm{~cm}$ diameter) placed on a motion-sensitive platform. Two speakers are in the chamber, one that generates background white noise $(65 \mathrm{~dB})$, and the other transmitting the signal. The session was initiated with a 5 -min acclimatization period followed by 5 presentations of the acoustic startle pulse alone (110 dB for $40 \mathrm{~ms}$ ), which were excluded from the statistical analysis. This was followed by the random presentation of either the pulse alone, or the pulse with a 10-ms 6-, 9-, 12-, 15- or 18-dB prepulse above background stimuli (so prepulses were $71,74,77,80$ or $83 \mathrm{~dB}$ ). This prepulse was presented $50 \mathrm{~ms}$ prior to the pulse. Each startle or prepulse was presented 3 times in a randomized fashion. The intertest interval was set to between 15 and $30 \mathrm{~s}$ and the trials were conducted with the house lights on. Startle response was recorded every millisecond for $65 \mathrm{~ms}$ following the onset of acoustic startle pulse. Maximal peak-to-peak amplitude was used to determine the ASR in the acoustic startle pulse and/or prepulse alone trials. PPI is expressed as percentage inhibition of the basal startle.

\section{Results}

\section{Open Field Test}

Spontaneous activity of WT and Fmrl KO mice was measured in the open field test. Animals were evaluated on distance travelled in a 30-min period and their average velocity during that time period. Mice were also evalu- ated on the percentage of time they spent in the inner area of the arena versus the wall areas.

We found that Fmr1 KO mice travelled significantly further than WT mice (increase of $32 \%, \mathrm{p}<0.05$; fig. 1a), and had a greater average velocity ( 80 vs. $61 \mathrm{~mm} / \mathrm{s}, \mathrm{p}<$ 0.05; fig. 1b). These findings suggest that Fmr1 KO mice on an FVB background exhibit hyperactive behavior, consistent with previous reports of mice on this background [9]. No differences were observed across genotypes regarding the percent of time the mice spent in the center of the maze, a measure sensitive to anxiety levels (WT: $13.6 \pm 1.8 \%$, Fmrl KO: $15.3 \pm 2.2 \%$ ).

THIP-treated mice also underwent analysis, and as sedation is an important factor when using $\mathrm{GABA}_{\mathrm{A}}$ agonists, we carefully monitored injected mice. At the dose used $(3 \mathrm{mg} / \mathrm{kg})$, we saw no indication of sedation in either the WT or Fmr1 KO mice, and THIP did not cause any effect on distance travelled or velocity in WT mice (fig. 1a, b). In contrast, THIP administration in Fmrl KO mice significantly attenuated both the distance travelled and velocity to WT levels ( $\mathrm{p}<0.05$ compared to Fmrl KO mice baseline; fig. 1a, b). This finding demonstrates that THIP rescues hyperactivity in Fmrl KO mice.

\section{Contextual and Cued Fear Conditioning}

To determine if the absence of FMRP has an effect on acquisition of the task, freezing behavior was recorded in the 2-min intervals immediately following the tone and shock. Both Fmr1 KO and WT mice had identical freezing patterns indicating that FMRP is not required for learning this task (fig. 2a). The mice were tested for contextual fear $24 \mathrm{~h}$ after training, and both Fmrl KO and WT mice displayed identical freezing, remaining immobile for approximately $36 \%$ of the trial period (fig. 2 b). Two hours after the contextual test, we probed for the 


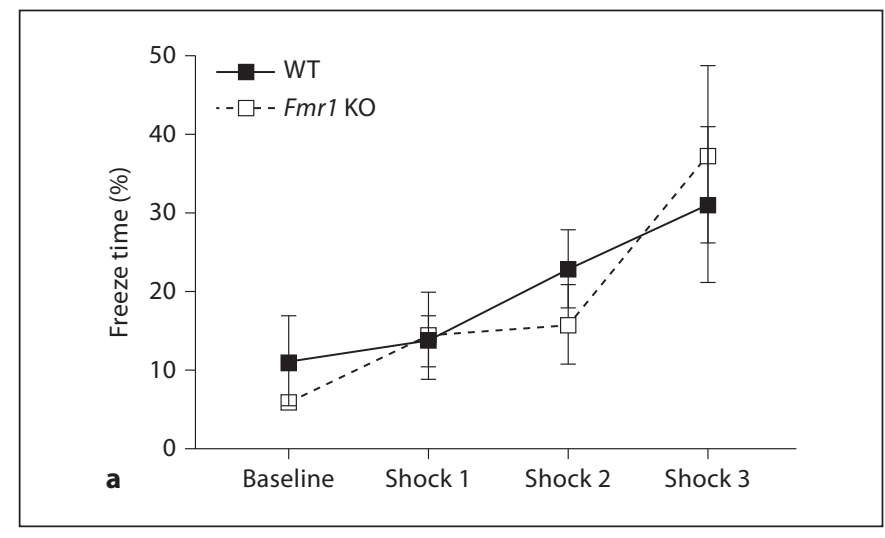

Fig. 2. Fmr1 KO mice have decreased cued, but not contextual, fear conditioning. a Acquisition of conditioned fear in WT and Fmrl KO mice. Freeze time was measured as a percent of the trial block ( $2 \mathrm{~min}$ ). Three shocks were presented to the mice followed by a 2-min interval. b Percent freeze time in contextual and cued testing $24-26 \mathrm{~h}$ after training. ${ }^{*} \mathrm{p}<0.05$, unpaired t test. c The effects of THIP administration $30 \mathrm{~min}$ prior to cued fear testing. ${ }^{*} \mathrm{p}<0.05$ vs. Fmr1 KO (control). ANOVA and Newman Keuls post hoc. $\mathrm{n}=8$ per group.

cued response. The mice were placed in a chamber with altered walls, floors, ceiling shape and odor. After a 2-min exploration, they were presented with the same auditory cue that preceded the footshock in the training period. Freezing behavior was measured, and WT mice froze for 25\% of the trial period compared to 9\% for Fmrl KO mice, a statistically significant difference ( $\mathrm{p}<0.05$; fig. $2 \mathrm{~b}$ ).

We repeated our experiments, but this time included THIP treatment $30 \mathrm{~min}$ prior to the cued fear test. Mice were treated with THIP $30 \mathrm{~min}$ prior to entering the novel arena. Interestingly, while THIP administration significantly reduced freezing in the WT mice, it did not alter the low freezing response in Fmr1 KO mice (fig. 2c; $\mathrm{p}<0.01$ ), indicating that enhancing tonic GABAergic transmission via THIP does not have an effect on cued fear conditioning in Fmrl KO mice.

\section{Auditory Startle Testing and PPI}

Auditory startle and PPI are measures of sensorimotor gating, which is the ability of an animal to integrate sensory information. The response to auditory startle was significantly impaired in Fmrl KO mice, being reduced by $65 \%$ ( $\mathrm{p}<0.01$; fig. $3 \mathrm{a}$ ). PPI in Fmr1 $\mathrm{KO}$ mice was significantly increased with all prepulses, but was more pro-
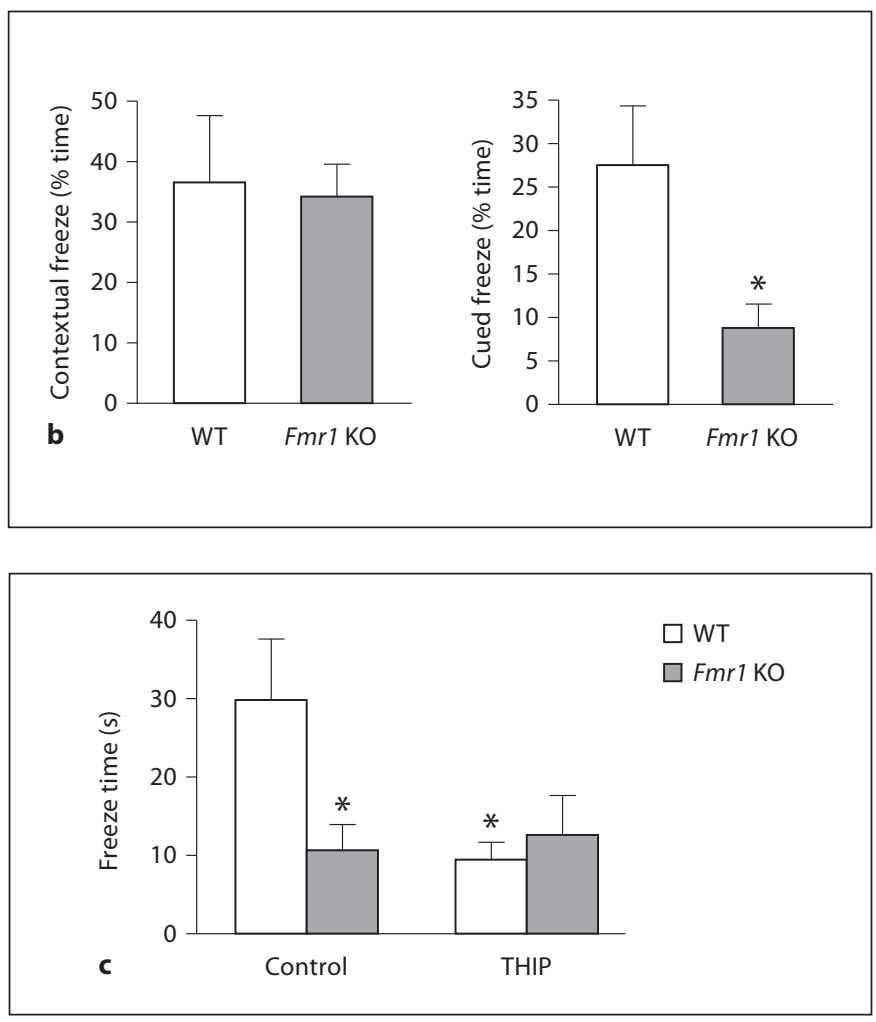

nounced with lower decibel prepulses [287\% increase (6 dB), 72\% (9 dB), 72\% (12 dB), 61\% (15 dB), 56\% (18 dB); $\mathrm{p}<0.01$ for all prepulses; fig. 3b].

THIP treatment did not alter the startle response in Fmrl KO mice, with treated mice having a 58\% decrease in startle size (fig. 3a). While THIP treatment also had no effect on PPI in WT mice, THIP did cause changes in PPI in Fmrl $\mathrm{KO}$ mice (fig. 3b). At low prestimulus intensity (6 $\mathrm{dB}$ above background), there was attenuation of PPI in THIP-treated mice compared to controls $(\mathrm{p}<0.05$; fig. 3b). As the prestimulus was increased to $74 \mathrm{~dB}(9 \mathrm{~dB}$ above background), THIP prevented the significant difference between WT and Fmrl KO mice (fig. 3b). As the prepulse volume increased above $74 \mathrm{~dB}$, the effect of THIP disappeared.

To enable a proportional comparison between control and THIP-treated mice, we converted the PPI data to percent WT (comparing control-WT to control-KO, and THIP-WT to THIP-KO). Using this scale, the effect of THIP treatment at low decibel prepulses becomes apparent. At $6 \mathrm{~dB}$, Fmrl $\mathrm{KO}$ mice have a 287\% increase in PPI, but Fmr1 KO THIP-treated mice only have a 109\% increase ( $178 \%$ reduction; $\mathrm{p}<0.01$; fig. $3 \mathrm{c}$ ). When the prepulse was $9 \mathrm{~dB}$ above background, Fmr1 KO mice have a $72 \%$ higher 


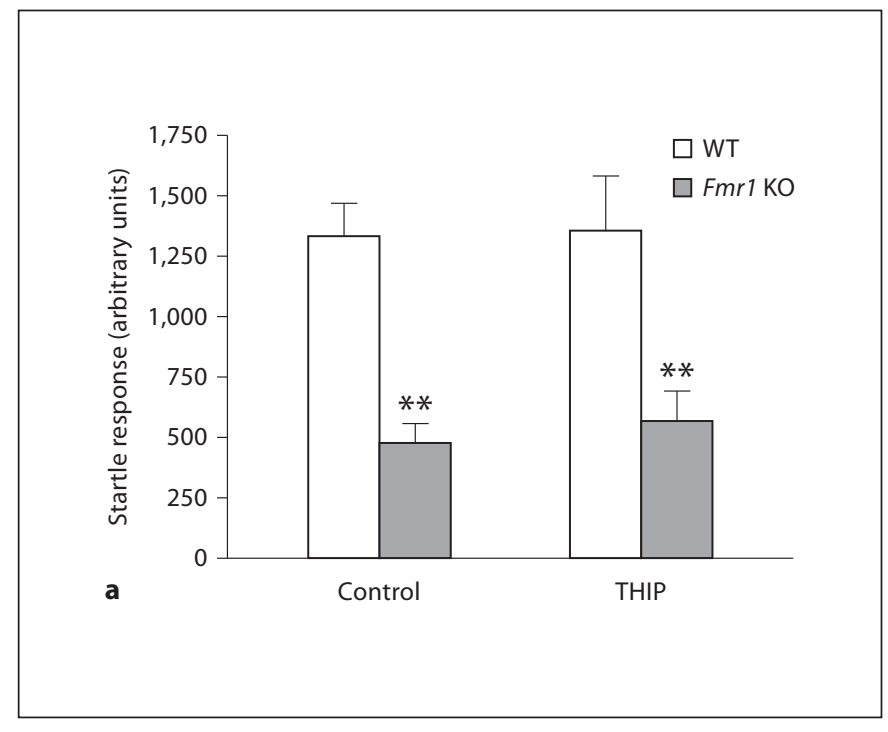

Fig. 3. THIP attenuates the Fmr1 KO-induced increase in PPI. a The startle response of WT and Fmrl KO mice to a 120-dB white noise pulse is not affected by THIP treatment $30 \mathrm{~min}$ prior to entering the sound chamber. $\mathbf{b}$ PPI is significantly increased in Fmr1 $\mathrm{KO}$ mice compared to WT controls. The greatest difference between genotypes is observed with the lower decibel prepulses. This effect is blunted in THIP-treated mice, but only at low decibel prepulses. The $\mathrm{x}$-axis displays prepulse in $\mathrm{dB}$ above background $(65 \mathrm{~dB}){ }^{* *} \mathrm{p}<0.01 ;{ }^{* *} \mathrm{p}<0.001 ; \mathrm{n} . \mathrm{s} .=$ non-significant vs. WT (control). ${ }^{\#} \mathrm{p}<0.05$; ${ }^{\# \#} \mathrm{p}<0.01$; ${ }^{\# \#} \mathrm{p}<0.001$; n.s. $=$ nonsignificant vs. WT (THIP). ANOVA with Newman Keuls post hoc (performed individually for each prepulse volume). c Change in PPI in Fmr1 KO mice as a percentage of WT mice. WT mouse response was set at 100\%. THIP-treated Fmrl KO mice were compared to THIP-treated WT mice. Fmrl KO control mice were compared to WT control mice. ${ }^{*} \mathrm{p}<0.05 ;{ }^{* *} \mathrm{p}<0.01$, unpaired t test. Fmr1 KO (control) vs. Fmr1 KO (THIP). $\mathrm{n}=8$ per group.

PPI, but THIP-treated Fmrl KO mice only have a $21 \%$ increase in PPI (a $51 \%$ reduction; $\mathrm{p}<0.05$; fig. $3 \mathrm{c}$ ). As the prepulse volume increased, the attenuation of PPI by THIP decreased compared to WT. These data confirm earlier findings that Fmr1 KO mice have different sensitivities to audible cues depending on the volume $[25,28]$, and demonstrate that THIP can partially reverse these deficits.

\section{Discussion}

Development of potentially effective treatments in humans for FXS relies on understanding the underlying brain defects as well as being able to genetically and/or pharmacologically correct synaptic, behavioral and cog-
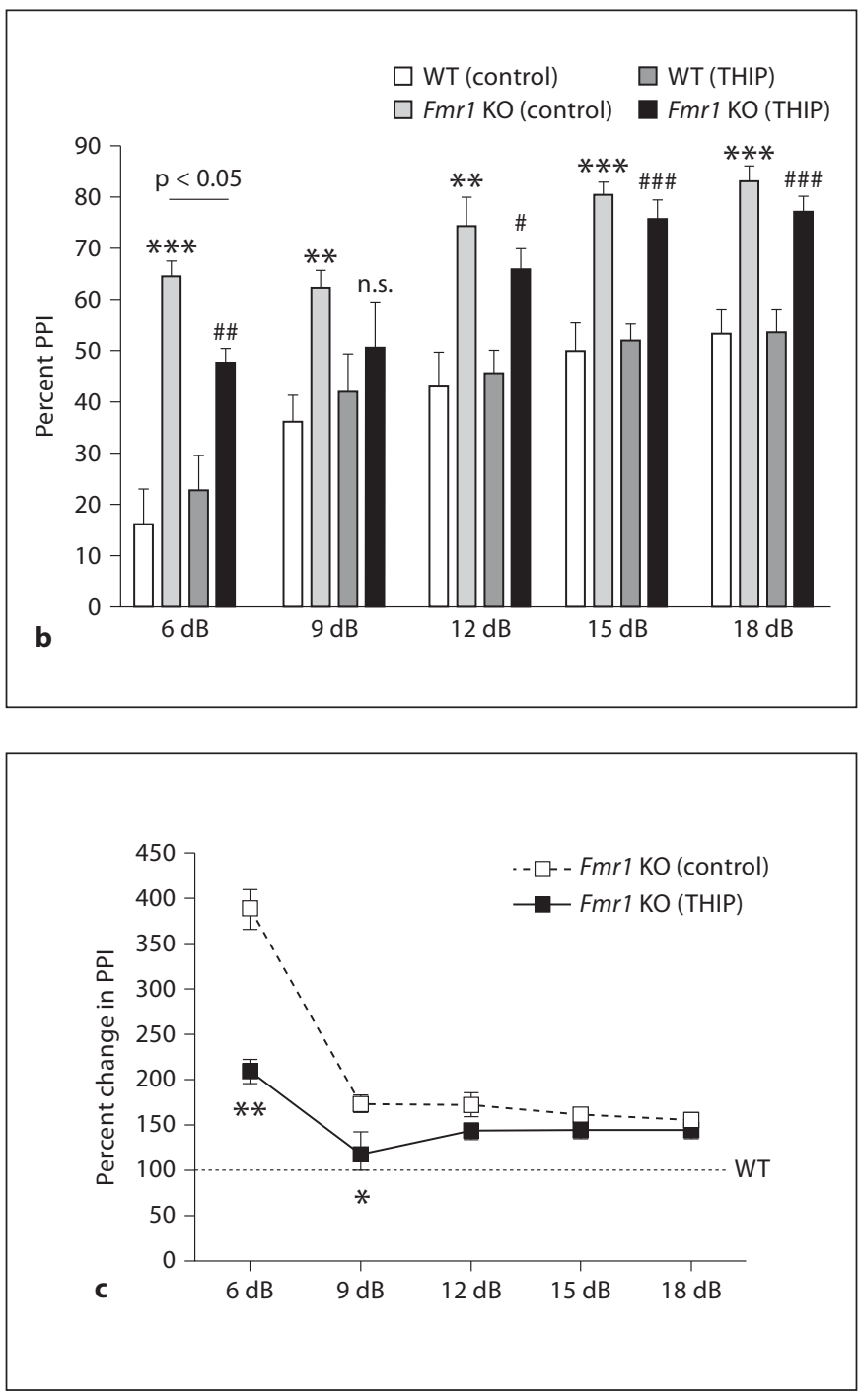

nitive abnormalities in the Fmrl KO mouse model. In the present study, we provide evidence that treatment with THIP, a $\mathrm{GABA}_{\mathrm{A}}$ agonist which acts upon tonic GABA receptors, attenuates the motor hyperactivity and sensory hypersensitivity in Fmrl KO mice. As THIP is not of the typical benzodiazepine class of GABA agonists, this suggest that tonic inhibition may be a major target for drug therapy and furthers the concept that $\mathrm{GABA}_{\mathrm{A}}$ receptors are a viable therapeutic target for this disorder as previously postulated [19].

Mounting evidence implicates the GABAergic system, and specifically the tonic form of inhibition, as a potential therapeutic target for developing novel treatments for other brain disorders such as epilepsy, premenstrual dysphoric disorder and stroke [22, 29-31]. In relation to FXS, 
it has been reported that GABA exposure during development can rescue the biochemical, morphological, and behavioral phenotypes of the Drosophila model of FXS [20], and taurine, a $\mathrm{GABA}_{\mathrm{A}}$ receptor agonist, improves cognitive functions in a mouse model of FXS [21]. In this study, we have used THIP, a superagonist at $\delta$-subunitcontaining perisynaptic and extrasynaptic $\mathrm{GABA}_{\mathrm{A}}$ receptors, and as such has its strongest effects on tonic inhibition [32]. Interestingly, direct binding between FMRP and the mRNA of the $\delta$-subunit of the $\mathrm{GABA}_{\mathrm{A}}$ receptor has been shown in Fmrl KO mice [33]. In addition, expression of this subunit is disrupted with a reduction of protein levels in Fmrl KO mice [16], consistent with a previous study showing downregulation of tonic GABAergic inhibition in the subiculum [15], supporting the concept that tonic inhibition is defective in Fmrl KO mice. Indeed, we have recently shown that tonic inhibitory currents are decreased in the amygdala in Fmrl KO mice, and bath application of THIP rescues neuronal hyperexcitability in the amygdala of Fmrl KO slice cultures [18]. Consistent with this, here we provide evidence that THIP can correct specific behavioral abnormalities in Fmrl KO mice that are relevant to the human condition.

Hyperactivity is one of the often-cited behavioral abnormalities in FXS $[34,35]$, and has also been previously reported in Fmr1 KO mice on the FVB background [9, 36, 37]. In this study, we report the presence of this hyperactivity, and its susceptibility to THIP administration. We believe that this dampening of hyperactivity is not due to sedative effects of THIP as $3 \mathrm{mg} / \mathrm{kg}$ had no effect on ambulation or velocity in control mice.

Methylphenidate, a psychostimulant drug commonly used to modify hyperarousal and hyperactivity in FXS, which mainly targets the dopamine system, also targets the noradrenergic system. Methylphenidate appears to enhance inhibitory synaptic transmission in the locus ceruleus in juvenile rats [38]. Since it has been reported that local GABAergic interneurons might play a role gating locus ceruleus function [39], the major brain region for noradrenergic transmission, it is intriguing to speculate that $\mathrm{GABA}_{\mathrm{A}}$ receptors are downregulated in the locus ceruleus, as has been reported in several other brain regions in FXS [16]. Therefore, enhancing GABAergic transmission might restore some degree of inhibition onto noradrenergic cells, therefore lowering hyperactivity in Fmrl $\mathrm{KO}$ mice.

Many groups, with variable results, have studied the behavioral phenotype of the Fmr1 KO mouse with regard to fear conditioning. The background strain appears to be an important factor in the appearance of many of these phenotypes [24, 40, 41], and even amongst laboratories using a similar background strain the results remain inconsistent. For example, in the present study, we report that cued, but not contextual, fear conditioning is altered in Fmr1 KO mice, while Paradee et al. [24] reported a decrease in both contextual and cued freezing. Given our previous results on the effects of THIP on excitability in the amygdala of Fmrl KO mice [18], we were very interested in examining the effect of THIP on Fmrl KO mice behavior in amygdala-dependent behavioral paradigms. However, we found that THIP administration $30 \mathrm{~min}$ prior to the recall test could not ameliorate the behavioral deficit observed in Fmrl KO mice. Instead we found that it significantly decreased the freezing time of control mice. This effect is probably due to the anxiolytic effect of $\mathrm{GABA}_{\mathrm{A}}$ agonists that has previously been reported [42]. As Fmrl KO mice were already at the lower end of the freezing detection scale, this effect was not seen in Fmrl KO mice. Taking together, our results and similar studies in cued fear conditioning [24] as well as physiological studies showing decreased long-term potentiation in the lateral amygdala $[43,44]$ suggest that Fmr1 KO mice have amygdala-based learning and memory deficits regarding the cued auditory fear conditioning. This may explain why Fmr1 KO mice have diminished fear responses such as freezing behavior. Increasing evidence supports that inhibition within the amygdala plays a central role in gating pre- and postsynaptic plasticity in the lateral amygdala, the major nucleus receiving sensory input from different brain regions, and therefore in fear-related behaviors (review in Ehrlich et al. [59]). We have recently described a profound defective GABAergic transmission in the basolateral nucleus of the amygdala [18], but to our knowledge there is not a single study focusing on GABAergic transmission within the lateral amygdala in Fmrl KO mice. Since decreasing GABAergic transmission can improve learning or retrieval of conditioned fear memories and impairs extinction memory retrieval in a contextspecific manner [45-47], it might be possible that GABAergic transmission is enhanced in the lateral amygdala, and reducing GABAergic transmission might have different outcomes in this behavioral paradigm.

Another core problem in individuals with FXS is the increase in sensitivity to auditory stimuli [48-50]. This hypersensitivity can be reproduced in Fmrl KO mice as abnormal ASR and PPI responses. Increased excitability in the ascending auditory pathway due to reduced $\mathrm{GABA}_{\mathrm{A}}$ receptor-mediated inhibition has been postulated as a possible mechanism for diminished startle response in Fmr1 KO mice [51]. Nevertheless, our re- 
sults seem to rule out this possibility since enhancing GABAergic transmission with THIP treatment did not alter the startle response in Fmrl KO mice. Furthermore, studies have shown that Fmrl KO mice have increased PPI of auditory startle $[25,28]$. Nielsen et al. [25] found that Fmr1 KO mice on a C57/Bl6 background had a significant elevation in PPI when presented with a prepulse $2 \mathrm{~dB}$ above background, but not a prepulse 4 or $8 \mathrm{~dB}$ above background. Chen and Toth [28] used Fmrl KO mice on an FVB background and found that a prepulse $10 \mathrm{~dB}$ above background enhanced the PPI by $96 \%$ compared to control mice, but only by $56 \%$ at $20 \mathrm{~dB}$ above background. In the present study, we found that Fmrl KO mice on the FVB background had a $287 \%$ increase in PPI at $6 \mathrm{~dB}$, but this could be volume dependently decreased to $72 \%$ at $9 \mathrm{~dB}$ and to $56 \%$ at $18 \mathrm{~dB}$. These changes in PPI could be due to the increased sensitivity of Fmr1 KO mice to low-intensity bursts, causing an increased PPI at low prepulses. THIP dampened the elevation in the PPI response back towards control levels; however, it only had an effect in the low-intensity prepulse window. The greatest effect was seen with the $6-\mathrm{dB}$ prepulse, where THIP reduced the PPI by $128 \%$. A strong effect was also observed when using the $9-\mathrm{dB}$ prepulse, as THIP reduced PPI by $51 \%$. As the volume of the prepulse increased, the effect of THIP was lost. One possible explanation for this partial restoration is that it is known that PPI is regulated by many neurotransmitter systems, including the GABAergic system [52, 53], making highly complex a complete restoration of PPI targeting only one of the systems involved. Furthermore, one study in Fmrl KO mice has shown decreased PPI of startle eyelid responses with the magnetic distance measurement [23]. This correlates with findings in humans with FXS [54, 55], and thus supports a role for FMRP in sensorimotor processing both in humans and mice. Interestingly, recent studies using THIP, which we have shown to have amygdala effects [18], have also demonstrated the existence of a potent tonic inhibitory neurotransmission in the rat auditory thalamus [56] and in the avian nucleus laminaris [57], suggesting an active role of tonic inhibition in modulating auditory processing cues.

In conclusion, we have demonstrated that Fmr1 KO mice have behavioral deficits in numerous behavioral paradigms, and that administration of the tonic $\mathrm{GABA}_{\mathrm{A}}$ receptor agonist THIP can ameliorate some of these core defects. Thus, these data extend our previous results showing that THIP rescues core electrophysiological deficits in Fmrl KO neurons [18], and strongly supports the hypothesis that enhancing tonic inhibition may be a putative target for the treatment of FXS. These data are especially intriguing as recent very promising phase II clinical trials in FXS indicate that $\mathrm{GABA}_{\mathrm{B}}$ receptor agonists such as R-Baclofen (STX209, Seaside Therapeutics) have a positive outcome for amygdala-based symptoms such as social avoidance. Interestingly, a clinical trial is already scheduled to study the effect of ganaxolone, a neurosteroid with high affinity for the $\delta$-subunit of $\mathrm{GABA}_{\mathrm{A}}$ receptors, in children with FXS at the MIND Institute of the University of California at Davis [58]. Thus, it is intriguing to speculate that the $\delta$-subunit of $\mathrm{GABA}_{\mathrm{A}}$ receptors might be a promising target for treatment in FXS. Indeed, based on the results presented here combined with our previous study with THIP [18], we predict that this trial will also have a positive outcome for amelioration of amygdala-based and nonamygdala-based symptoms in FXS.

\section{Acknowledgments}

This work was supported by the Hazeltine Foundation (J.G.C.), the Neurodevelopment Disorders Fund (J.G.C.), the FRAXA Research Foundation (J.G.C.), Autism Speaks (J.G.C.) and the National Institute on Neurological Disorders and Stroke (MPB NS067417). We thank Karen Gale and Patrick Forcelli for their assistance with their ASR and PPI equipment.

\section{References}

THIP Ameliorates Specific Behavioral

Deficits in Fragile X Syndrome
1 Turner G, Webb T, Wake S, Robinson H: Prevalence of fragile X syndrome. Am J Med Genet 1996;64:196-197.

-2 Hagerman RJ, Berry-Kravis E, Kaufmann WE, Ono MY, Tartaglia N, Lachiewicz A, Kronk R, Delahunty C, Hessl D, Visootsak J, Picker J, Gane L, Tranfaglia M: Advances in the treatment of fragile X syndrome. Pediatrics 2009; 123:378-390.

-3 Antar LN, Li C, Zhang H, Carroll RC, Bassell G): Local functions for FMRP in axon growth cone motility and activity-depen- dent regulation of filopodia and spine synapses. Mol Cell Neurosci 2006;32:37-48.

-4 Christie SB, Akins MR, Schwob JE, Fallon JR: The FXG: a presynaptic fragile X granule expressed in a subset of developing brain circuits. J Neurosci 2009;29:1514-1524.

$\checkmark 5$ Comery TA, Harris JB, Willems PJ, Oostra BA, Irwin SA, Weiler IJ, Greenough WT: Abnormal dendritic spines in fragile $\mathrm{X}$ knockout mice: maturation and pruning deficits. Proc Natl Acad Sci USA 1997;94: 5401-5404. 
6 Cruz-Martin A, Crespo M, Portera-Cailliau C: Delayed stabilization of dendritic spines in fragile X mice. J Neurosci 2010;30:77937803.

7 Zhang J, Hou L, Klann E, Nelson DL: Altered hippocampal synaptic plasticity in the fmrl gene family knockout mouse models. J Neurophysiol 2009;101:2572-2580.

8 McNaughton CH, Moon J, Strawderman MS, Maclean KN, Evans J, Strupp BJ: Evidence for social anxiety and impaired social cognition in a mouse model of fragile $\mathrm{X}$ syndrome. Behav Neurosci 2008;122:293-300.

$\checkmark 9$ Mineur YS, Sluyter F, de Wit S, Oostra BA, Crusio WE: Behavioral and neuroanatomical characterization of the fmrl knockout mouse. Hippocampus 2002;12:39-46.

-10 Bakker CE VC, Willemsen R, van der Helm R, Oerlemans F, Vermey M, Bygrave A, Hoogeveen AT, Oostra BA, Reyniers E, et al, The Dutch-Belgian Consortium: Fmrl knockout mice: a model to study fragile $\mathrm{X}$ mental retardation. Cell 1994;78:23-33.

-11 Dolen G, Osterweil E, Rao BS, Smith GB, Auerbach BD, Chattarji S, Bear MF: Correction of fragile X syndrome in mice. Neuron 2007; 56:955-962.

12 McBride SM, Choi CH, Wang Y, Liebelt D, Braunstein E, Ferreiro D, Sehgal A, Siwicki KK, Dockendorff TC, Nguyen HT, McDonald TV, Jongens TA: Pharmacological rescue of synaptic plasticity, courtship behavior, and mushroom body defects in a drosophila model of fragile X syndrome. Neuron 2005; 45:753-764.

13 Brown V, Jin P, Ceman S, Darnell JC, O'Donnell WT, Tenenbaum SA, Jin X, Feng Y, Wilkinson KD, Keene JD, Darnell RB, Warren ST: Microarray identification of FMRP-associated brain mRNAs and altered mRNA translational profiles in fragile $\mathrm{X}$ syndrome. Cell 2001;107:477-487.

14 Centonze D, Rossi S, Mercaldo V, Napoli I, Ciotti MT, De Chiara V, Musella A, Prosperetti C, Calabresi P, Bernardi G, Bagni C: Abnormal striatal GABA transmission in the mouse model for the fragile $\mathrm{X}$ syndrome. Biol Psychiatry 2008;63:963-973.

- 15 Curia G, Papouin T, Seguela P, Avoli M: Downregulation of tonic GABAergic inhibition in a mouse model of fragile $\mathrm{X}$ syndrome. Cereb Cortex 2009; 19:1515-1520.

16 D’Hulst C, De Geest N, Reeve SP, Van Dam D, De Deyn PP, Hassan BA, Kooy RF: Decreased expression of the GABAA receptor in fragile X syndrome. Brain Res 2006;1121: 238-245.

-17 El Idrissi A, Ding XH, Scalia J, Trenkner E, Brown WT, Dobkin C: Decreased GABA(A) receptor expression in the seizure-prone fragile X mouse. Neurosci Lett 2005;377: 141-146.
18 Olmos-Serrano JL, Paluszkiewicz SM, Martin BS, Kaufmann WE, Corbin JG, Huntsman MM: Defective GABAergic neurotransmission and pharmacological rescue of neuronal hyperexcitability in the amygdala in a mouse model of fragile X syndrome. J Neurosci 2010;30:9929-9938.

19 D'Hulst C, Kooy RF: The GABAA receptor: a novel target for treatment of fragile X? Trends Neurosci 2007;30:425-431.

20 Chang S, Bray SM, Li Z, Zarnescu DC, He C, Jin P, Warren ST: Identification of small molecules rescuing fragile $\mathrm{X}$ syndrome phenotypes in Drosophila. Nat Chem Biol 2008;4: 256-263.

21 El Idrissi A, Boukarrou L, Dokin C, Brown WT: Taurine improves congestive functions in a mouse model of fragile X syndrome. Adv Exp Med Biol 2009;643:191-198.

22 Glykys J, Mody I: The main source of ambient GABA responsible for tonic inhibition in the mouse hippocampus. J Physiol 2007;582: 1163-1178.

23 de Vrij FM, Levenga J, van der Linde HC, Koekkoek SK, De Zeeuw CI, Nelson DL, Oostra BA, Willemsen R: Rescue of behavioral phenotype and neuronal protrusion morphology in Fmrl KO mice. Neurobiol Dis 2008;31:127-132.

24 Paradee W, Melikian HE, Rasmussen DL, Kenneson A, Conn PJ, Warren ST: Fragile X mouse: strain effects of knockout phenotype and evidence suggesting deficient amygdala function. Neuroscience 1999;94:185-192.

25 Nielsen DM, Derber WJ, McClellan DA, Crnic LS: Alterations in the auditory startle response in Fmrl targeted mutant mouse models of fragile $\mathrm{X}$ syndrome. Brain Res 2002;927:8-17.

26 Loane DJ, Pocivavsek A, Moussa CE, Thompson R, Matsuoka Y, Faden AI, Rebeck GW, Burns MP: Amyloid precursor protein secretases as therapeutic targets for traumatic brain injury. Nat Med 2009;15:377-379.

27 Mandillo S, Tucci V, Holter SM, Meziane H, Banchaabouchi MA, Kallnik M, Lad HV, Nolan PM, Ouagazzal AM, Coghill EL, Gale K, Golini E, Jacquot S, Krezel W, Parker A, Riet F, Schneider I, Marazziti D, Auwerx J, Brown SD, Chambon P, Rosenthal N, Tocchini-Valentini G, Wurst W: Reliability, robustness, and reproducibility in mouse behavioral phenotyping: a cross-laboratory study. Physiol Genomics 2008;34:243-255.

28 Chen L, Toth M: Fragile X mice develop sensory hyperreactivity to auditory stimuli. Neuroscience 2001;103:1043-1050.

29 Clarkson AN, Huang BS, Macisaac SE, Mody I, Carmichael ST: Reducing excessive GABAmediated tonic inhibition promotes functional recovery after stroke. Nature 2010; 468:305-309.

30 Gajcy K, Lochynski S, Librowski T: A role of GABA analogues in the treatment of neurological diseases. Curr Med Chem 2010;17: 2338-2347.
31 Maguire JL, Stell BM, Rafizadeh M, Mody I: Ovarian cycle-linked changes in GABA(A) receptors mediating tonic inhibition alter seizure susceptibility and anxiety. Nat Neurosci 2005;8:797-804.

-32 Semyanov A, Walker MC, Kullmann DM, Silver RA: Tonically active GABAA receptors: modulating gain and maintaining the tone. Trends Neurosci 2004;27:262-269.

- 33 Miyashiro KY, Beckel-Mitchener A, Purk TP, Becker KG, Barret T, Liu L, Carbonetto S, Weiler IJ, Greenough WT, Eberwine J: RNA cargoes associating with FMRP reveal deficits in cellular functioning in Fmrl null mice. Neuron 2003;37:417-431.

34 Cornish K, Munir F, Wilding J: A neuropsychological and behavioural profile of attention deficits in fragile $\mathrm{X}$ syndrome. Rev Neurol 2001;33(suppl 1):S24-S29.

35 Cornish KM, Turk J, Wilding J, Sudhalter V, Munir F, Kooy F, Hagerman R: Annotation: deconstructing the attention deficit in fragile X syndrome: a developmental neuropsychological approach. J Child Psychol Psychiatry 2004;45:1042-1053.

36 Liu ZH, Chuang DM, Smith CB: Lithium ameliorates phenotypic deficits in a mouse model of fragile X syndrome. Int J Neuropsychopharmacol 2011;14:618-630.

37 Yan QJ, Asafo-Adjei PK, Arnold HM, Brown RE, Bauchwitz RP: A phenotypic and molecular characterization of the fmrl-tmlcgr fragile X mouse. Genes Brain Behav 2004;3: 337-359.

38 Kidani Y, Ishimatsu M, Akasu T: Methylphenidate enhances inhibitory synaptic transmission by increasing the content of norepinephrine in the locus coeruleus of juvenile rats. Kurume Med J 2010;57:29-38.

39 Aston-Jones G, Zhu Y, Card JP: Numerous GABAergic afferents to locus ceruleus in the pericerulear dendritic zone: possible interneuronal pool. J Neurosci 2004;24:23132321.

40 Hayashi ML, Rao BS, Seo JS, Choi HS, Dolan BM, Choi SY, Chattarji S, Tonegawa S: Inhibition of p21-activated kinase rescues symptoms of fragile $\mathrm{X}$ syndrome in mice. Proc Natl Acad Sci USA 2007;104:11489-11494.

41 Van Dam D, D’Hooge R, Hauben E, Reyniers E, Gantois I, Bakker CE, Oostra BA, Kooy RF, De Deyn PP: Spatial learning, contextual fear conditioning and conditioned emotional response in fmrl knockout mice. Behav Brain Res 2000;117:127-136.

42 Rupprecht R, Eser D, Zwanzger P, Moller HJ: GABAA receptors as targets for novel anxiolytic drugs. World J Biol Psychiatry 2006;7: 231-237.

43 Suvrathan A, Hoeffer CA, Wong H, Klann E, Chattarji S: Characterization and reversal of synaptic defects in the amygdala in a mouse model of fragile X syndrome. Proc Natl Acad Sci USA 2010;107:11591-11596. 
\4 Zhao MG, Toyoda H, Ko SW, Ding HK, Wu LJ, Zhuo M: Deficits in trace fear memory and long-term potentiation in a mouse model for fragile X syndrome. J Neurosci 2005; 25:7385-7392.

45 Guarraci FA, Frohardt RJ, Young SL, Kapp BS: A functional role for dopamine transmission in the amygdala during conditioned fear. Ann NY Acad Sci 1999;877:732-736.

46 Harris JA, Westbrook RF: Evidence that GABA transmission mediates context-specific extinction of learned fear. Psychopharmacology (Berl) 1998;140:105-115.

-47 Tang Y, Wang F, Xie G, Liu J, Li L, Su L, Liu Y, Hu X, He Z, Blumberg HP: Reduced ventral anterior cingulate and amygdala volumes in medication-naive females with major depressive disorder: a voxel-based morphometric magnetic resonance imaging study. Psychiatry Res 2007;156:83-86.

48 Hagerman RJ: Physical and behavioral phenotype; in Cronister A (ed): Fragile X Syndrome: Diagnosis, Treatment and Research. Baltimore, The Johns Hopkins University Press, 1996, pp 3-87.
49 Miller LJ, McIntosh DN, McGrath J, Shyu V, Lampe M, Taylor AK, Tassone F, Neitzel K, Stackhouse T, Hagerman RJ: Electrodermal responses to sensory stimuli in individuals with fragile $\mathrm{X}$ syndrome: a preliminary report. Am J Med Genet 1999;83:268-279.

50 Rojas DC, Benkers TL, Rogers SJ, Teale PD, Reite ML, Hagerman RJ: Auditory evoked magnetic fields in adults with fragile $\mathrm{X}$ syndrome. Neuroreport 2001;12:2573-2576.

51 Yun SW, Platholi J, Flaherty MS, Fu W, Kottmann AH, Toth M: Fmrp is required for the establishment of the startle response during the critical period of auditory development. Brain Res 2006;1110:159-165.

52 Arai S, Takuma K, Mizoguchi H, Ibi D, Nagai T, Takahashi K, Kamei H, Nabeshima T, Yamada K: Involvement of pallidotegmental neurons in methamphetamine- and MK801-induced impairment of prepulse inhibition of the acoustic startle reflex in mice: reversal by $\mathrm{GABAB}$ receptor agonist baclofen. Neuropsychopharmacology 2008;33:31643175.

53 Bortolato M, Frau R, Orru M, Piras AP, Fa M, Tuveri A, Puligheddu M, Gessa GL, Castelli MP, Mereu G, Marrosu F: Activation of GABA(B) receptors reverses spontaneous gating deficits in juvenile DBA/2J mice. Psychopharmacology (Berl) 2007;194:361-369.
54 Frankland PW, Wang Y, Rosner B, Shimizu T, Balleine BW, Dykens EM, Ornitz EM, Silva $A J$ : Sensorimotor gating abnormalities in young males with fragile $\mathrm{X}$ syndrome and fmr1-knockout mice. Mol Psychiatry 2004;9: 417-425.

55 Hessl D, Berry-Kravis E, Cordeiro L, Yuhas J, Ornitz EM, Campbell A, Chruscinski E, Hervey C, Long JM, Hagerman RJ: Prepulse inhibition in fragile $\mathrm{X}$ syndrome: feasibility, reliability, and implications for treatment. Am J Med Genet B Neuropsychiatr Genet 2009;150B:545-553.

56 Richardson BD, Ling LL, Uteshev VV, Caspary DM: Extrasynaptic GABA(A) receptors and tonic inhibition in rat auditory thalamus. PLoS One; 6:e16508.

57 Tang ZQ, Dinh EH, Shi W, Lu Y: Ambient GABA-activated tonic inhibition sharpens auditory coincidence detection via a depolarizing shunting mechanism. J Neurosci 2011;31:6121-6131.

58 Cornish K, Turk J, Hagerman R: The fragile $\mathrm{X}$ continuum: new advances and perspectives. J Intellect Disabil Res 2008;52:469482.

59 Ehrlich I, Humeau Y, Grenier F, Ciocchi S, Herry C, Lüthi A: Amygdala inhibitory circuits and the control of fear memory. Neuron 2009;62:757-771. 